Acta Cryst. (1977). B33, 279-280

\title{
Radioprotectant S,2-Aminoethylisothiouronium Bromide Hydrobromide
}

\author{
By Kalyani Vijayan and A. Mani \\ Materials Science Division, National Aeronautical Laboratory, Bangalore 560017, India
}

(Received 26 April 1976; accepted 12 September 1976)

\begin{abstract}
C}_{3} \mathrm{H}_{11} \mathrm{~N}_{3} \mathrm{SBr}$. $\mathrm{HBr}$ (AET Br. $\mathrm{HBr}$ ), $M_{r}=$ 281.0 , triclinic $P 1, a=7.206, b=8 \cdot 272, c=8.640 \pm$ $0.008 \AA$, $\alpha=72.4, \beta=81.0, \gamma=89.8 \pm 0.5^{\circ}, D_{m}$ (flotation in a mixture of bromoform and ethyl acetate) $=1.94, D_{c}=1.93 \mathrm{~g} \mathrm{~cm}^{-3}$. The amino $\mathrm{N}$ and the $\mathrm{S}$ atoms in the molecule are trans and there is no indication of intramolecular $\mathrm{S}-\mathrm{N}$ attraction. The crystal structure is stabilized by a network of $\mathrm{NH} \cdots \mathrm{Br}$ hydrogen bonds.
\end{abstract}

Introduction. Transparent, prismatic crystals of AET $\mathrm{Br} . \mathrm{HBr}$ were picked from the sample supplied by Sigma Chemical Co. Three-dimensional intensity data from six reciprocal levels were recorded on multiple films by the equi-inclination Weissenberg technique with Ni-filtered $\mathrm{Cu}$ radiation. The intensities of $625 \mathrm{ob}-$ served reflexions were measured visually and were

Table 1. Fractional atomic coordinates $\left(\times 10^{3}\right)$ E.s.d.'s are given in parentheses.

$\begin{array}{lccc} & x & y & z \\ \mathrm{Br}(1) & -191 \cdot 3(9) & 836 \cdot 8(7) & -11 \cdot 5(6) \\ \mathrm{Br}(2) & -230 \cdot 3(9) & 222 \cdot 8(7) & 459 \cdot 8(8) \\ \mathrm{S} & 439(2) & 463(2) & 233(2) \\ \mathrm{N}(1) & 126(6) & 122(5) & 652(4) \\ \mathrm{N}(2) & 80(6) & 551(6) & 193(5) \\ \mathrm{N}(3) & 336(7) & 754(6) & 53(6) \\ \mathrm{C}(1) & 245(6) & 282(6) & 543(5) \\ \mathrm{C}(2) & 303(8) & 266(6) & 367(5) \\ \mathrm{C}(3) & 254(8) & 587(8) & 159(6)\end{array}$

corrected for Lorentz and polarization factors, spotshape and absorption effects.

The distribution of heavy-atom vectors in the threedimensional Patterson map clearly indicated the space group to be $P \overline{1}$. The structure was solved by the heavyatom method and refined to $R=\Sigma|| F_{o}|-| F_{c}|| / \Sigma\left|F_{o}\right|$ $=0.118$ by block-diagonal structure factor leastsquares calculations with unit weights for all the observed reflexions and individual isotropic thermal parameters. Further refinement with a weighting scheme of the form $w=1 / a+b F_{o}+C F_{o}^{2}$ where $a=1 \cdot 0, b=$ -0.01 and $C=0.0023$ and anisotropic thermal parameters reduced $R$ to 0.089 when the least-squares refinement converged. The atomic scattering factors used were those of Cromer \& Waber (1965). The final positional and thermal parameters are given in Tables 1 and 2 respectively.*

Discussion. AET $\mathrm{Br}$. $\mathrm{HBr} \quad\left[\mathrm{NH}_{2}-\mathrm{CH}_{2}-\mathrm{CH}_{2}-\mathrm{S}-\right.$ $\left.\mathrm{C}\left(=\mathrm{NH}_{2}^{+} \mathrm{Br}^{-}\right)-\mathrm{NH}_{2} . \mathrm{HBr}\right]$, is well known as a radioprotective aminothiol (Doherty \& Burnett, 1955). When administered, AET transguanylates to mercaptoethylguanidine (MEG) which is the active form. As part of a systematic programme of X-ray analyses of radioprotectants (Vijayan, Mani, Vedavathi \& Ramaseshan, 1975; Ramaseshan \& Vijayan, 1976), the

* A list of structure factors has been deposited with the British Library Lending Division as Supplementary Publication No. SUP 32105 (4 pp.). Copies may be obtained through The Executive Secretary, International Union of Crystallography, 13 White Friars, Chester CH1 1NZ, England.

Table 2. Anisotropic thermal parameters $\left(\times 10^{3}\right)$ of the form:

$\exp \left[-\left(\beta_{11} h^{2}+\beta_{22} k^{2}+\beta_{33} l^{2}+2 \beta_{12} h k+2 \beta_{13} h l+2 \beta_{23} k l\right)\right]$, with e.s.d.'s in parentheses

\begin{tabular}{lrrrrrr} 
& $\beta_{11}$ & $\beta_{22}$ & $\beta_{33}$ & $\beta_{12}$ & $\beta_{13}$ & \multicolumn{1}{c}{$\beta_{23}$} \\
$\operatorname{Br}(1)$ & $24(2)$ & $19(1)$ & $16(1)$ & $3(1)$ & $-5(1)$ & $-5(1)$ \\
$\operatorname{Br}(2)$ & $19(2)$ & $20(1)$ & $26(1)$ & $7(1)$ & $-6(1)$ & $-7(1)$ \\
$\mathrm{S}$ & $16(4)$ & $15(2)$ & $16(2)$ & $3(2)$ & $-3(2)$ & $-2(2)$ \\
$\mathrm{N}(1)$ & $18(12)$ & $15(7)$ & $12(6)$ & $2(7)$ & $5(6)$ & $-1(5)$ \\
$\mathrm{N}(2)$ & $15(11)$ & $20(8)$ & $17(7)$ & $-2(8)$ & $8(7)$ & $-4(7)$ \\
$\mathrm{N}(3)$ & $20(13)$ & $26(10)$ & $24(9)$ & $4(10)$ & $-1(8)$ & $-9(9)$ \\
$\mathrm{C}(1)$ & $8(11)$ & $24(10)$ & $14(8)$ & $-2(10)$ & $-10(8)$ & $-2(8)$ \\
$\mathrm{C}(2)$ & $27(16)$ & $17(9)$ & $14(7)$ & $9(9)$ & $-13(9)$ & $-10(7)$ \\
$\mathrm{C}(3)$ & $25(17)$ & $25(11)$ & $16(8)$ & $18(12)$ & $4(9)$ & $-10(9)$ \\
& & & & & &
\end{tabular}


Table 3. Bond lengths and valency angles

E.s.d.'s are given in parentheses.

$\begin{array}{lll}\mathrm{N}(1)-\mathrm{C}(1) & 1.54(6) \AA & \mathrm{N}(1)-\mathrm{C}(1)-\mathrm{C}(2) \\ \mathrm{C}(1)-\mathrm{C}(2) & 1.56(7) & \mathrm{C}(1)-\mathrm{C}(2)-\mathrm{S} \\ \mathrm{C}(2)-\mathrm{S} & 1.86(4) & \mathrm{C}(2)-\mathrm{S}-\mathrm{C}(3) \\ \mathrm{S}-\mathrm{C}(3) & 1.76(6) & \mathrm{S}-\mathrm{C}(3)-\mathrm{N}(2) \\ \mathrm{C}(3)-\mathrm{N}(2) & 1.26(7) & \mathrm{S}-\mathrm{C}(3)-\mathrm{N}(3) \\ \mathrm{C}(3)-\mathrm{N}(3) & 1.47(7) & \mathrm{N}(2)-\mathrm{C}(3)-\mathrm{N}(3)\end{array}$

$109(4)^{\circ}$

$109(3)$

$100(3)$

$129(5)$

$108(4)$

$123(5)$

Table 4. Hydrogen-bonded $\mathrm{N}-\mathrm{Br}$ contacts $(\AA)$

\begin{tabular}{lccc}
\multicolumn{4}{c}{ E.s.d.'s are given in parentheses. } \\
$\mathrm{N}(1)^{\mathrm{i}}-\mathrm{Br}(2)^{\mathrm{i}}$ & $3 \cdot 24(4)$ & $\mathrm{N}(2)^{\mathrm{i}}-\mathrm{Br}(2)^{\mathrm{i}}$ & $3 \cdot 52(4)$ \\
$\mathrm{N}(1)^{\mathrm{i}}-\mathrm{Br}(2)^{\mathrm{ii}}$ & $3 \cdot 32(4)$ & $\mathrm{N}(3)^{\mathrm{i}}-\mathrm{Br}(1)^{\mathrm{iv}}$ & $3 \cdot 40(5)$ \\
$\mathrm{N}(1)^{\mathrm{i}}-\mathrm{Br}(1)^{\mathrm{iii}}$ & $3 \cdot 33(4)$ & $\mathrm{N}(3)^{\mathrm{i}}-\mathrm{Br}(1)^{\mathrm{v}}$ & $3 \cdot 47(5)$ \\
$\mathrm{N}(2)^{\mathrm{i}}-\mathrm{Br}(1)^{\mathrm{i}}$ & $3 \cdot 32(4)$ & &
\end{tabular}

Symmetry code: (i) $x, y, z$; (ii) $x, y, z+1$; (iii) $x, y+1$, $\bar{z}+1 ;$ (iv) $x+1, y, z ;$ (v) $x, y+2, \bar{z}$.

crystal structure of AET has been analysed. The final bond lengths and bond angles in the AET molecule are given in Table 3. As the heavy $\mathrm{Br}$ atoms in the structure account for 0.90 of the scattering matter in the unit cell, the parameters of the lighter atoms in the structure are determined with low accuracy. Consequently, the e.s.d.'s of the molecular dimensions are rather high.

The mean plane through the isothiouronium function defined by the atoms $\mathrm{S}, \mathrm{C}(3), \mathrm{N}(2)$ and $\mathrm{N}(3)$ indicates a planar arrangement, the largest displacement being $0.02 \AA$ for $\mathrm{C}(3)$. The dimensions of the isothiouronium function are comparable within experimental error to those found in the crystal structures of $S$-methylthiouronium $p$-chlorobenzoate (Kennard \& Walker, 1963) and $S$-methylisothiourea sulphate (Stam, 1962). A striking feature observed in these structures is that two of the nominally equivalent valency angles at the $\mathrm{C}$ atom differ by nearly $10^{\circ}$, the third angle formed by the $\mathrm{N}$ atoms being, however, normal. In AET $\mathrm{Br}$. $\mathrm{HBr}$ also, despite the fact that the e.s.d.'s are large, the angle $\mathrm{S}-\mathrm{C}(3)-\mathrm{N}(2)$ is significantly larger than $\mathrm{S}-\mathrm{C}(3)-\mathrm{N}(3)$. In the crystal structure of 2-mercaptoethylamine hydrochloride (Jandacek \& Swartz, 1970), another aminothiol radioprotectant, the amino $\mathrm{N}$ and the $\mathrm{S}$ atoms are in the gauche conformation and there is an indication of attractive, intramolecular $\mathrm{S}-\mathrm{N}$ interaction. In contrast, in AET $\mathrm{Br}$. $\mathrm{HBr}$, the amino $\mathrm{N}$ and the $\mathrm{S}$ atoms are trans. This conformation eliminates the possibility of any attractive interaction between $\mathrm{S}$ and $\mathrm{N}(1)$. The ethyl $\mathrm{C}(2)$ and

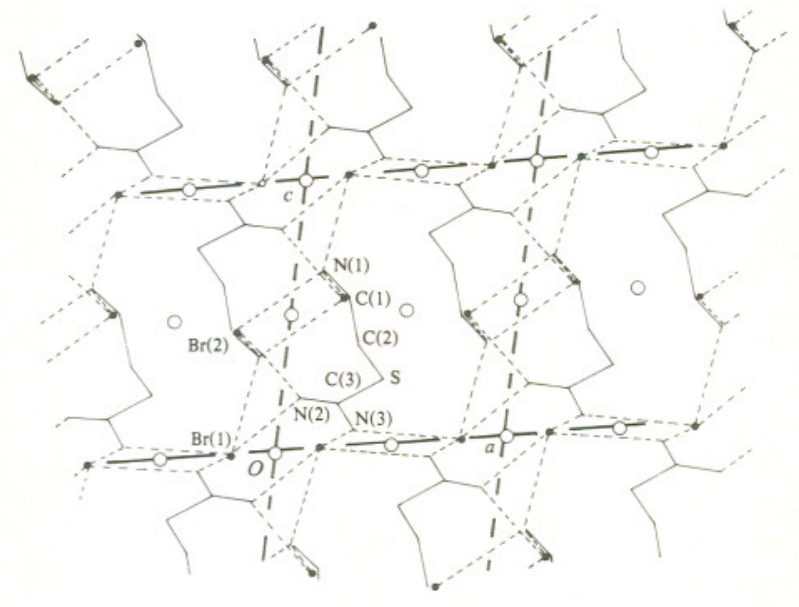

Fig. 1. View of the crystal structure as seen along $\mathbf{b}$. The black circles and the broken lines represent the bromine atoms and the hydrogen bonds respectively.

$\mathrm{N}(2)$ of the isothiuronium function are in the cis conformation, and $\mathrm{C}(2)$ and $\mathrm{N}(3)$ are trans.

The crystal structure as seen along $\mathbf{b}$ is shown in Fig. 1. There are ten crystallographically independent $\mathrm{N}-\mathrm{Br}$ contact distances less than $4 \AA$ of which seven appear on geometrical considerations to be hydrogen bonds. They are listed in Table 4 and are also shown in Fig. 1. The amino $\mathrm{N}(1)$ is involved in three hydrogen bonds. The three $\mathrm{Br}$ atoms hydrogen-bonded to $\mathrm{N}(1)$ and the covalently linked $\mathrm{C}(1)$ are distributed nearly tetrahedrally about $\mathrm{N}(1)$. $\mathrm{N}(2)$ and $\mathrm{N}(3)$ of the isothiouronium function appear to be involved in two hydrogen bonds each. $\mathrm{C}(3), \mathrm{N}(2), \mathrm{N}(3)$ and the four $\mathrm{Br}$ atoms hydrogen-bonded to $\mathrm{N}(2)$ and $\mathrm{N}(3)$ lie nearly in a plane.

The authors wish to thank Dr S. Ramaseshan for his kind interest in the problem.

\section{References}

Cromer, D. T. \& WAber, J. T. (1965). Acta Cryst. 18, 104-109.

Doherty, D. G. \& Burnett, W. T. JR (1955). Proc. Soc. Exp. Biol. Med. 89, 312-314.

JANDACEK, R. J. \& SWARTZ, H. M. (1970). Radiat. Res. 44, 523-530.

Kennard, O. \& Walker, J. (1963). J. Chem. Soc. pp. 5513-5533.

RamaSEShan, S. \& ViJayAn, K. (1976). Curr. Sci. 45, 49.

Stam, C. H. (1962). Acta Cryst. 15, 317-322.

Vijayan, K., Mani, A., Vedavathi, B. M. \& Ramaseshan, S. (1975). Acta Cryst. A31, S58. 